\title{
The Desire that Propels Entrepreneurial Intentions
}

\section{Hernan E. Riquelme ${ }^{1}$ and Abdullah Al Lanqawi}

\begin{abstract}
The purpose of this paper is to integrate conceptual and empirical work on the prediction and explanation of entrepreneurial intentions. Specifically, it tests a model that accounts for the motivation of the entrepreneur, a salient factor commonly omitted in current theories of entrepreneurial intentions. We test the role of entrepreneurial desire (a distinct concept from desirability) as a determinant of two distinctive entrepreneurial intentions. This research corroborates recent findings that highlight the importance of identifying intentions to start a business with an orientation for growth as opposed to income substitution. Further, while the role of emotions has become an important factor in entrepreneurship, anticipated emotions have received very little attention in the prevailing literature. Using a sample from Kuwait, this paper finds that desire is a stronger predictor of growth-oriented intentions than income-substitution intentions. Also, entrepreneurial desire partially mediates the effects between attitude, anticipated emotions and entrepreneurial intentions.
\end{abstract}

Keywords: Entrepreneurship, intentions, desire, attitude, anticipated emotions.

\section{INTRODUCTION}

The extant literature refers to two dominant theories or models to analyse entrepreneurship as intentional behavior, namely, the Theory of Planned Behavior (TBP) and the Shapero Entrepreneurial Event (SEE) model (Bird, 2015; Van Gelderen, Kautonen \& Fink, 2015). Despite the efficacy of both models in predicting intentions (variances have been reported between $21 \%$ and $40 \%$ (Krueger, Reilly \& Carsrud, 2000; Schlaegel \& Koenig, 2014), predictors of intention in the TPB theory do not provide sufficient or necessary reasons for the formation of intention (Bagozzi, 1992; Fazio, 1995). Similarly, the predictors included in the SEE model omit the motivational component of intention, a critique that has been voiced recently in the context of

1 Hernan E. Riquelme, PhD. College of Business, Gulf University for Science and Technology, Block 5, building 1, Mubarak Al-Abdullah area/West Mishref, Kuwait, e-mail: riquelme.h@gust.edu.kw

2 Abdulla M. Al-Lanqawi, Fund Manager, in Al-Amin Money Market Fund, Ahli United Bank Kuwait. P.O.Box 71, Safat, 12168 Kuwait. 
entrepreneurship (van Gelderen et al., 2015). Attitudes towards a behavior in the TPB, or the 'perceived desirability' construct in the SEE model, are evaluative appraisals of an action and as such only reflect an individual's preference but, unless accompanied by a desire to act, an intention will not be forthcoming (Perugini \& Bagozzi, 2001). The perceived desirability concept rests on the valence of an action's end state, that is, the value ascribed to alternative wants and wishes at a pre-decisional phase (Gollwitzer, 1996; Gollwitzer, Heckhausen \& Steller, 1990). Ergo, there is no commitment towards a goal as yet. Desire, however, is "a state of mind whereby an agent has a personal motivation to perform an action or to achieve a goal (Perugini \& Bagozzi, 2004, p. 71)". The motivation derives from an integration of various sources of appraisals, for example, evaluative, social and emotional. It should be noted that the relationship between desires and intentions is acknowledged by philosophers (Davis, 1984), yet it has seldom been tested in the prevailing literature. Only studies that follow goal-directed behavior models appear to examine this salient relationship (Bagozzi \& Dholakia, 2006; Perugini \& Bagozzi, 2001). The desire concept, in particular, has gained traction more recently in entrepreneurship literature. A comment from McMullen and Dimov (2013, p.1481) appears to suggest this: "if anything remains constant throughout the journey of entrepreneurship, it is the desire intention for profit" (emphasis added).

In a meta-analysis of empirical studies on entrepreneurial intentions, Schlaegel and Koenig (2014) acknowledged that the desirability concept, in either the TPB or the SEE model, does not carry motivational content; therefore, they borrow the concept of 'goal-desires' from the goal-directed behavior model and integrate it into their model. The authors, however, do not analyse the concept of desirability (Bird, 2015) and state the concept is comparable with the perceived desirability construct in the SEE model defined as "the degree to which an individual feels attracted to become an entrepreneur and reflects individual preferences for entrepreneurial behavior (Schlaegel \& Koenig, 2014, p. 294)". This definition, without a doubt, reflects an attitude rather than a concept of desire as intended in the goal-directed behavior model. Desire is distinct from attitude, as will be discussed in a later section. Importantly, prevailing models of entrepreneurial intentions appear to disregard this difference, and omit the desire-intentions relationship altogether.

While some studies on entrepreneurial intentions acknowledge the absence of the volitional component of intentions (e.g., (Krueger, et al., 2000; Schlaegel \& Koenig, 2014), a construct that accounts for the motivational component of intention is still lacking in the relevant literature. Early studies tried to account for this omission and included the concept of 
perceived desirability and propensity to act (Krueger, 1993; Krueger et al., 2000; Schlaegel \& Koenig, 2014). These studies however, have not so far distinguished desirability as an attitude from desires as a motivation. Also, existing models of entrepreneurial intentions fail to account for the emotional reactions to a contemplated action, an important omission considering the growing interest of emotions in the field of entrepreneurship (Cardon, Foo, Shepherd \& Wiklund, 2012). Finally, Bird (2015) has called for studies of entrepreneurial intentions that predict more than just business formation, and that investigate alternative entrepreneurial actions, for instance, growth intentions. Our goals in this research are to address the aforementioned issues. In particular, we build a model of entrepreneurial intention that extends the TPB. For this purpose, we draw on the Goal-Directed Behavior model to justify the inclusion of desire and anticipated emotions in the TPB. Hence, our article provides an in-depth conceptualization and analysis of the variables forming entrepreneurial desire as a mediator of attitudes, anticipated emotions, subjective norms and behavioral control on intention. This paper then explores more specific predictions of entrepreneurial intentions. We accomplish this by drawing on recent work from Douglas (2013) who distinguishes entrepreneurs that start a business with an orientation for growth from those that form a business for the sake of income substitution.

\section{LITERATURE REVIEW}

In this section, we review two critiques of the TPB. Drawing from the Goaldirected Behavior model (Perugini \& Bagozzi, 2004), we expand the TPB by adding the concept of Anticipated Emotions (positive and negative) and Desire as a mediator of attitudes, subjective norms, anticipated emotions, and perceived behavioral control on intentions.

According to the TPB, entrepreneurial intentions are formed by the attitude (appeal or personal attractiveness) towards behavior, social norms (the sense of 'ought-ness' internalized by individuals and imposed upon them by the social environment), and perceived behavioral control (Ajzen, 1985). Although parsimonious, the TPB has been criticized for disregarding personal motivation to achieve certain goal outcomes in predicting intentions (Perugini \& Conner, 2000). Several modifications to the theory have been suggested, for example, incorporating self-identity, moral norms, anticipated emotions, desires, and clarifying the distinction between self-efficacy and behavioral control in TPB model (Perugini \& Bagozzi, 2001). The assumption that attitudes influence intentions directly has been questioned (Bagozzi \& Dholakia, 2006). Attitudes are not expected to affect intentions, and when they have done, it has been in conjunction with social support (an interaction 
effect - and not an additive effect as proposed in the TPB), also known as 'contingent consistency'(Andrews \& Kandel, 1979). Further, individuals may elicit a positive attitude towards an object or action, yet they may not have the intention to act, even in the presence of social pressures (subjective norms) and perceived behavioural control ( Perugini \& Bagozzi, 2004). Hence, attitude can contribute to an intention if "certain social psychological conditions are either co-present or forthcoming as accompanying instigators of intentions" (Bagozzi, 1992, p. 184). For instance, Grube and Morgan (1990) found that an interactive effect between attitude and perceived social support increased the prediction of adolescent smoking, drinking and drug use. Also, the entrepreneurial intentions literature appears to overlook the relationship between motivation and intentions. Shapero's entrepreneurial event (SEE) model posits that entrepreneurial intentions could be predicted using three variables: perceived desirability, perceived feasibility and propensity to act. The latter construct is an acknowledgement that intentions are necessary but not sufficient to carry out an action. According to Krueger et al. (2000), without the propensity to act, significant action may not be taken. However, the inclusion of this variable in SEE models is problematic, since the measures used to proxy for 'propensity to act' (e.g. the illusion of control scale found in Kueger and Carsrud (1993) or the Seligman's learned optimism scale used in Krueger et al. (2000)) are similar to measures of perceived behavioral control in the TPB, and perceived feasibility in the SEE. These measures, thus, overlap, create ambiguity and diminish potential inferences about intentions from both models (Schlaegel \& Koenig, 2014).

\section{The role of desire and entrepreneurial intentions}

To account for the missing motivational link in the attitude-intention relationship of the TPB, Bagozzi (1992) proposes a construct called 'desire', akin to the concept of wants or wishes as found in Gollwitzer's action phase model (Bagozzi \& Dholakia, 2006), or 'volitive desire' (Davis, 1984). According to Bagozzi, (1992, p. 184) the desire to do something implies a "motivational commitment to do it." Intentions, by themselves, do not carry this commitment but entail desires to do so, for instance, if a person intends to eat, $s /$ he must want to do it (Davis, 1984). Desires represent the motivational state of mind and have the capacity to transform appraisals and reasons (e.g. the attitudes, subjective norms, and perceived desirability) to act into a motivation to do so ( Perugini \& R. Bagozzi, 2001). Later studies by Bagozzi and others refer to these desires as 'implementation desires'(Bagozzi, Dholakia \& Basuroy, 2003). In new developments of attribution theory, Malle and Knobe (1997) also recognize the importance of the desire construct and 
conclude the attribution of intention requires, among other factors, that the subject has a desire for an outcome. Note that desires are distinct from intentions: desires are psychological states that reflect what one wants or wishes, whereas intentions are what one plans to do (Mellers \& Chang, 1994).

Volitive desires do not lead directly to action, but influence intentions the conscious commitment to act (Miller and Pasta, 1995). Earlier we claimed that desires, or volitive desires, are distinct from an attitude. Volitive desires are based on reasons, and are influenced by value judgements (attitudes). If an individual believes something is good, valuable, right or just, $\mathrm{s} / \mathrm{he}$ will tend to want it to exist (Davis, 1984). Attitudes act as a catalyst to release a hidden desire (Bagozzi, 1992). The desire-intention sequence of causality has been hypothesized and tested in various contexts. Childbearing desires have been found to be the primary determinant of childbearing intentions (Mellers \& Chang, 1994), bodyweight regulation, and effort spent studying (Teasdale \& Barnard, 1993). With respect to the domain of entrepreneurship, the concept of perceived desirability (an attitude) to creating a new business has been examined in the prevailing literature and used in model formulations (Fitzimmons \& Douglas, 2011; Krueger, 1993; Krueger et al., 2000). In all cases, perceived desirability has played an important role in entrepreneurial intentions.

Recent meta-analyses of entrepreneurial intention have referred to entrepreneurial intentions as the "intention of an individual to start a new business" (Schlaegel \& Koenig, 2014) or "desires to own or start a business" (Bae, Qian, Miao \& Fiet, 2014). Bird (2015) has suggested researchers further refine their research of entrepreneurial intentions, since it is now well established in the literature that two types of entrepreneurs exist. 'Opportunity entrepreneurs' are those who start a business to exploit unique opportunities. 'Necessity entrepreneurs' are those who form businesses out of a necessity for income, that is, to survive poverty and/or unemployment (Cheung, 2014; Desai, 2011; Reynolds, Camp, Bygrave, Autio \& Hay, 2002). The distinction between opportunity and necessity entrepreneurs is important because opportunity firms are more efficient than necessity ones (i.e. they generate more sales per worker employed (Amin, 2009; Douglas, 2013)). Recently, Douglas (2013) developed a scale to discriminate between entrepreneurs who possess growth-oriented intentions (Opportunity entrepreneurs) and those who have independence-oriented intentions (Necessity entrepreneurs). Sampling from a group of 106 MBA students from Thailand, Douglas finds the antecedents of growth-oriented intentions differ from those that are independent-oriented. Entrepreneurs possessing the former traits are more likely to be male, bear a negative attitude towards work enjoyment, and have high expected self-efficacy. Entrepreneurs with 
independent oriented intentions however, have lower risk tolerance, possess less expected self-efficacy, and prefer greater autonomy.

Against the previous review, we hypothesize that $(\mathrm{H} 1 \mathrm{a})$ entrepreneurial volitive desire is the closest determinant of both intentions (growth and necessity. Logically, regardless of the type of intention, an individual must be aware of and accept his or her own desire to act before forming an intention (Davis, 2011). The stronger the desire to start a business, the stronger the intention is towards that end objective.

However, $\mathrm{H} 1$ (b) posits that entrepreneurial volitive desire will have a greater impact on individuals who have an intention to start a business with an orientation for growth as compared to those who seek to start a business with an orientation to become independent. The former requires greater sacrifice (e.g. work long hours or greater tolerance for work effort, an attitude to take higher risks) that justify a stronger desire to commit to forming a business.

\section{Anticipated emotions}

Another critique of the TPB is its emphasis on assuming rationality in the decision making process and ignoring affective processes that may exist (Sandberg \& Conner, 2008). Specifically, this research includes the role of anticipated emotions. Anticipated emotions, as defined by Pfister and Bohm $(2008$, p. 6), are 'beliefs about one's future emotional states that might ensue when the outcomes are obtained'. That is, individuals engage in counterfactual thinking or 'pre-factual appraisals' (Gleicher, Boninger, Strathman, Armor, Hetts \& Ahn, 1995), entertaining possible scenarios of what they would feel like if an outcome would not turn out as expected (Bagozzi \& Dholakia, 2006). Anticipated emotions play a critical role in influencing desire since individuals have been found to consider the ramifications of achieving and not achieving a specific goal (Bagozzi et al., 1998). For instance, if an outcome of a goal is expected to be pleasant, desires form to exhort an individual to move towards that goal. If the outcome is anticipated to be unpleasant, emotions may arise to form a non-desire, that is, a desire to avoid moving in the direction of the goal. Increasingly, research shows that anticipated emotions affect decisions in various domains such as eating junk food, using drugs and alcohol (Nelissen, de Vet \& Zeelenberg, 2011), gambling rather than saving money (Schlosser, Dunning \& Fetchenhauer (2013)), dieting and exercising (Perugini \& Bagozzi, 2001), and riding bikes (Bagozzi \& Dholakia, 2006).

In the prevailing entrepreneurship literature, work by Shepherd, Wilklund \& Haynie (2007) argues that anticipatory grief helps prepare entrepreneurs to cope with eventual business failure. Li (2011) found the interaction between 
hope and regret accounted for $58 \%$ of the variation in the subjective value of forming a new venture. Wood and Williams (2014) found counterfactual thinking, in the form of 'worst-case scenario considerations', was the most important characteristic in predicting the attractiveness of an opportunity; the attractiveness of an opportunity significantly diminished if the worstcase scenario of the opportunity was severe as opposed to mild. Recently, aanticipated emotions have been shown to moderate the effects of attitude and subjective norms on entrepreneurial intentions to start a business (Zampetakis, Lerakis, Kafetsios \& Moustakis 2016). From the evidence described above, one may conclude that individuals take into consideration the anticipated emotional consequences of both positive and negative outcomes. These emotions will directly affect the desire to either start or not a new business venture. Consequently, this article posits that anticipating the positive and negative outcomes of starting a business is instrumental for the development of a desire towards starting a business. This hypothesis is formalized as follows: $(\mathrm{H} 2 \mathrm{a})$ the more positive the anticipated emotions of the outcome of starting a business, the more the desire to start a business, conversely, $(\mathrm{H} 2 \mathrm{~b})$ the more negative the anticipated emotions the less the desire to start a business.

\section{The attitude-desire relationship}

Attitudes, as conceived in the TPB and similar cognitive models such as the SEE, are evaluative appraisals of an action and do not explain how evaluations translate into intentions. Consider for instance, an individual who has a positive attitude towards an object (e.g. a car) and has the resources to purchase it. This person may simply not want the object and an intention cannot be formed. In this example, desire acts as a mediator between attitude and intention. To explain this mechanism, Bagozzi (1992) refers to the work of Lazaru's theory of emotion and adaptation. For example, experiencing an unpleasant event leads a person to sadness or disappointment, which in turn leads to an intention to obtain help or support. Attitude has been widely used to predict entrepreneurial intentions (Bird, 2015; Schlaegel \& Koenig, 2014) but within the context of individual preferences. Shapero's model is one of the first in incorporating the concept of perceived desirability. However, perceived desirability, a specific attitude, reflects the valence (positive or negative) of an action's end state and is an inherent objective property of the end state itself and does not have the connotation of a personal motivation to achieve an end state. Krueger et al. (2000), for instance, used reflective measures of perceived desirability such as, "How tense would you be... [to start your business]"; "How enthusiastic would you be..." These statements reflect 
the valence of an attitude but lack the element of conation of the construct desire. Moreover, the authors measure the 'Global Perceived Desirability' which is analogous to the concept of desire, namely, "How desirable is it for you to start your own business?" Even in this case, the measure appears to capture more of the personal value that is attached to starting a business, than a personal motivation. Some empirical evidence illustrates that attitudes influence childbearing desires ( Miller, 1994), desires to exercise, diet, study, participate in online communities (Bagozzi \& Dholakia, 2006; Perugini \& Bagozzi, 2001; Perugini \& Conner, 2000), and participate in electronic word of mouth (Okasaki, 2009). In the context of entrepreneurship, we speculate that $(\mathrm{H} 3)$ the more individuals find entrepreneurship rewarding, enjoyable (positive attitudes), that is they appraise starting a new business as valued activity, the more they will desire to pursue entrepreneurial activities.

\section{Subjective norms}

Subjective norms have been posited to influence intention directly in the TPB. Individuals are more likely to form an intention insofar as perceived norms encourage or promote decision making. Empirically however, the extant literature on entrepreneurial intentions has found mixed evidence to support the subjective norms-intentions relationship (Bird, 2015).

In our model, subjective norms do not necessarily imply a commitment to an intention as they are not clearly connected (Bagozzi, 1992). It is the feelings or sentiments people develop within oneself and the perceived feelings from others (in a self-regulatory process similar to the appraisal process), that develop the motivation and in turn, the desire to form an intention. We suggest that individuals who intend to start a business will appraise the perception of significant others' expectations and feelings (whether favorable or unfavorable), and integrate these with their own perceptions to conform, thus, culminating certain feelings that will then feed into a desire. This suggests desire mediates the relationship between subjective norms and intentions. As a consequence of normative actions, a person may confront and integrate four situations: negative feelings toward a deviant significant other, negative feelings toward a deviant-self, positive feelings toward a significant other, and positive feelings toward a conforming self. For instance, individuals are highly influenced by their families' opinions in relation to starting a business. If their families believe they should not start a business (contrary to what they want), these would-be entrepreneurs may feel pressured to conform with their families' beliefs, engendering negative emotions (e.g. contempt, resentment, and reproach) and a negative desire to start a business. In their integrated model, Schlaegel and Koening (2014) 
reveal subjective norms have a direct effect on both perceived desirability and intentions. Consequently, we posit that the more individuals perceive their significant others have a strong and positive attitude towards them starting a business, the stronger the desire to start a business (H4).

\section{Perceived behavioral control}

Individuals will develop stronger intentions to perform an activity to the extent they perceive the action is under their volitional control, or they perceive themselves as competent to perform an action, that is, self-efficacy. Bandura (1997) suggested that self-efficacy beliefs regulate human functioning through cognitive, motivational, affective, and decisional processes, and the strongest factors that serve as motivators are "rooted in the core belief that one has the power to produce desired effects, otherwise one has little incentive to act or to persevere in the face of difficulties (Bandura \& Locke, 2003, p. 87)". Ajzen and Madden (1986) also recognize that predicting the behaviour of individuals who do not have control is problematic. Individuals must at least perceive they have some degree of control over their actions otherwise they will not follow through on their actions. For this reason, perceived behavioral control (PBC) was added to the Theory of Reasoned Action to improve predictions of intentions in situations where the action is only partially under a person's volitional control. Perceived behavioral control, Ajzen (1991) asserts, is similar to the concept of self-efficacy developed by Bandura (1997). However, this similitude has been questioned (Armitage \& Conner, 1999; Rodgers, Conner, \& Murray, 2008) and is beyond the scope of this study. Both constructs have been employed successfully in numerous research studies, including in the field of entrepreneurship, as predictors of intention (Krueger et al., 2000; Sitkin \& Weingart, 1995; Clore et al., 2001; Slovic, Finucane, Peters \& MacGregor, 2002; Kautonen, van Gelderen \& Fink, 2015). The self-efficacy concept has also been incorporated into Shapero's model under the label 'perceived feasibility' and was defined as the "degree to which one feels personally capable of starting a business" (Krueger et al., 2000 , p. 419). However, there is little evidence regarding the influence of self-efficacy in predicting the intentions of entrepreneurs with an orientation for growth and entrepreneurs for necessity. In the study conducted by Baum and Bird (2010), self-efficacy was an important moderator of successful entrepreneurial intelligence in CEOs and founders of high growth printing and graphic firms. The authors note: "HGEs (High Growth Entrepreneurs) must also be confident about their ability to apply their intelligence (Baum and Bird, 2010, p. 401)". Other empirical evidence finds high-growth businesses are formed by people who have high perceptions of self-efficacy (Baum \& 
Locke, 2004), and that individuals with increased levels of self-efficacy set higher goals (Franken, 1997). In an empirical study, Douglas (2013) suggests that individuals with lesser-expected self-efficacy will avoid growth-oriented firms and will be more associated with independence-oriented new ventures. He also expected that self-efficacy would be more associated with entrepreneurial intentions for growth. Growth-oriented firms require greater skills and resources to manage than independence-oriented businesses. Further, starting a new venture with the aim of growing exponentially likely requires much greater ambition from the entrepreneur's viewpoint. The results from Douglas (2013) indicate self-efficacy is not significantly related to intentions with an orientation for independence but is significant to intentions with an orientation for growth.

Taking this previous evidence, it is hypothesized that: $(\mathrm{H} 5 \mathrm{a})$ perceived behavioral control/self-efficacy will be positively associated with growthoriented intentions and $(\mathrm{H} 5 \mathrm{~b})$ with independence-oriented intentions. But (H5c) perceived behavioral control/self-efficacy will be more associated with growth-oriented intentions than with independence-oriented intentions.

Our model also proposes perceived behavioral control/self-efficacy directly influences desire. We support this relationship by using the rationale and evidence from the model of goal-directed behavior (Bagozzi et al., 1998), and the Interactive Cognitive Subsystems Conceptual Framework (Teasdale \& Barnard, 1993). The latter suggests the perception of personal inadequacy or incompetency is represented (stored as a schematic mental mode of a particular experience) as qualitatively different kinds of information. These patterns of sensory inputs, propositional, and implicational knowledge determines high-level meaning and emotional response that leads to a desire or avoidance. In the entrepreneurial context, different individuals will have stored experiences in their minds reflecting whether they have succeeded recently or failed at tasks, whether one's performance has been criticized by significant others, and from more directly censored-derived sources. For example, whether one's bodily arousal is high, or one's posture was erect or stooped, together, create an implicit schema of self-efficacy. This general self-reflection, as competent or incompetent at starting a new venture, will influence his or her sense of desire (or avoidance) to starting a new venture.

Hence: (H6) the more individuals perceive starting a business is under their control, the more they desire it.

Finally, and as per the previous description of the relationships in the model, we expect the influence of attitudes (perceived favorability of starting a business); belief (perceived behavioral control/self-efficacy, subjective norms) and affect (anticipated emotions) will be mediated by the desire to start a business (H7). 
Figure 1 illustrates our hypothesized relationships. The framework accounts for variables used in the TPB, namely, subjective norms, attitude, and perceived behavioral control, with the caveat that these do not have a direct influence on intention but are mediated by desire. Thus, desire, drawing from the Model of Goal-Directed Behavior, has an integrative function of the variables mentioned above. Perceived behavioral control is retained as in the TPB (i.e. a direct link to intention), and is based on the premise that an intention is expected to form if the person believes $s /$ he has the means and resources to perform the behavior or action (Ajzen, 1985). The addition to the TPB model is highlighted in shaded boxes and with a thicker solid arrow.

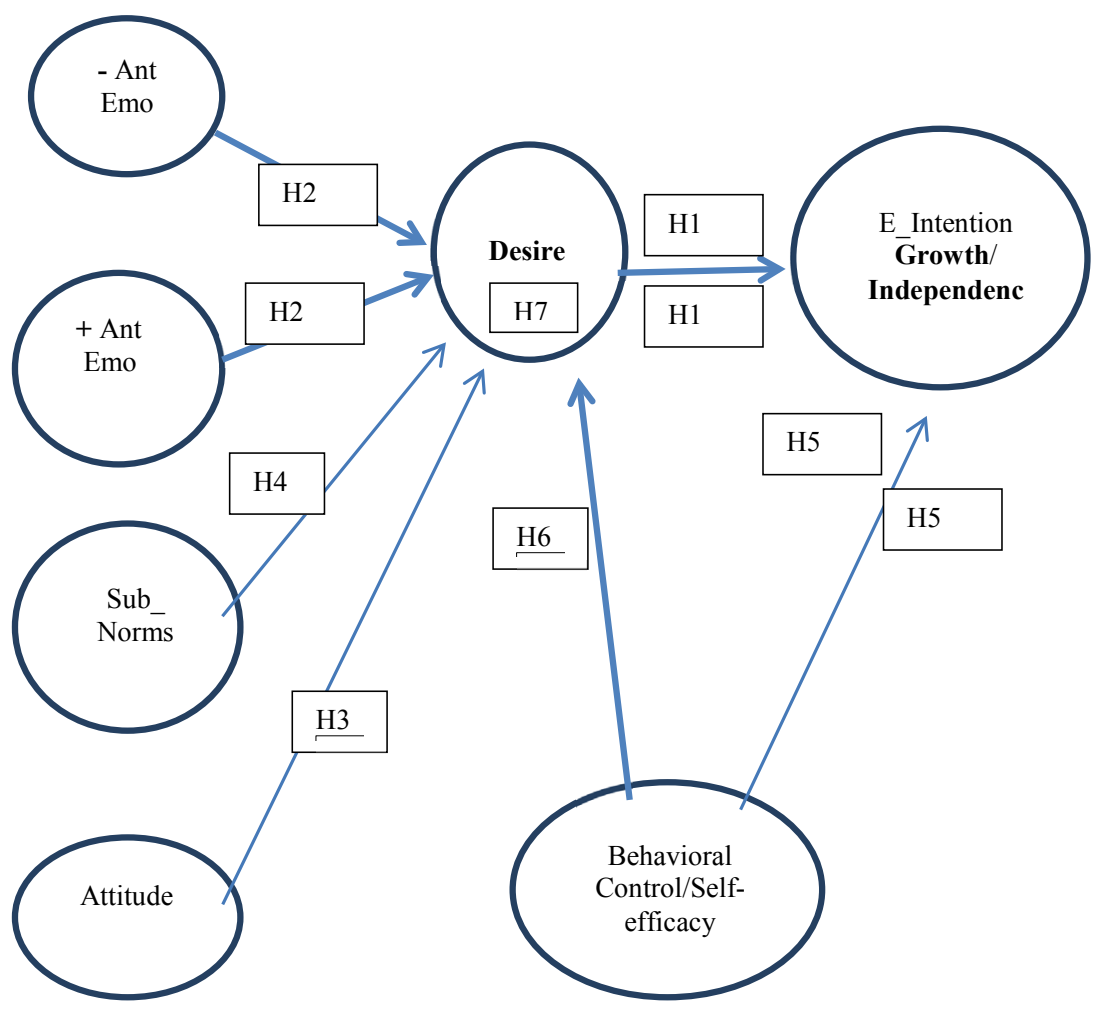

Legend: - Ant Emo $=$ Negative Anticipated Emotion, + Ant Emo $=$ Positive Anticipated Emotion, Sub_Norms = Subjective Norms, E_Intention = Entrepreneurial intention

Figure 1. Theoretical framework of entrepreneurial desire and intentions for growth or independence 


\section{RESEARCH METHODS}

\section{Participants and procedure}

Our sample consists of 214 respondents living in Kuwait who reported having intentions to start a business. Questionnaires, 600, were distributed to employees in banks and ministries, and another 450 questionnaires were emailed to alumni of a university. We assume that the aforementioned individuals are more likely to have intentions to start businesses since they are more exposed to business experiences, such as in banks, universities, or in ministries (note, ministries in Kuwait are open until 1:30 PM which provides employees with opportunities to start other initiatives if they so desire).

The response rate for this study was $20 \%$ with 211 cases used in the data analysis because three questionnaires were incomplete. The sampling method followed a non-probabilistic procedure and the sample self-selected. The characteristics of our sample are depicted in the Appendix. The majority of respondents was between 20 and 49 years old, male, married, and works within the private sector with several years of experience. All respondents have at least an undergraduate degree. The sample was divided into two groups based on individual responses to our entrepreneurial intention scale. Individuals who marked a preference of above 4 for all the independenceoriented items were considered to be entrepreneurs with independenceoriented intentions. Alternatively, individuals who marked above 4 for all the growth-oriented items were allocated into the growth oriented intentions group. The group containing individuals with independence and growth oriented intentions comprised of 90 and 108 subjects respectively. We analyzed both groups separately using our proposed model. We acknowledge the sample size maybe rather small, however, similar studies have used similar sample sizes, for example, Krueger et al. (2000) in their model comparison used 97 senior university students, and Douglas' (2013) sample comprised 106 second-year MBA students. Bird (2015) finds, in her review of studies of entrepreneurial intentions, that more than $80 \%$ of the studies used students. We note the post-hoc statistical power for a multiple regression given five predictors, and sample of 90 and 108 provide a power of 0.9999 and 0.998 respectively.

The data were analyzed using SmartPLS version 2.0. The technique has been widely used because of its flexibility in terms of the assumptions, for example, it can deal with both reflective and formative measures and it is robust when data moderately deviate from normality. 


\section{MEASURES}

Respondents were asked to respond to a number of interspersed items. For the sake of space, all measures, scale values, and sources can be requested from the author. To measure intentions with a growth or independent orientation, we used a scale adapted from Douglas (2013). An example of items in the scale is worded as follows: "how likely [ $1=$ very unlikely to $7=$ very likely] is it that you would want to start a new business venture that exploits a new technology that promises to have very good prospects for long term growth and eventual profitability? Attitude was measured on a seven-point interval scale using statements such as, 'starting a business is (1) punishing (7) rewarding' and 'starting a business is (1) disadvantageous (7) advantageous'. Respondents were asked to express their positive and negative anticipated emotions on statements such as: 'how do you expect (anticipate) to feel if you succeed in starting your own business: not at all (1) [happy] to (7) = very much so, [satisfied], [glad], [proud], [frustrated], [disappointed], [sad], [guilty], [worried]. Two items were used to measure self-efficacy and another two measure behavioral control such as, 'How much control would you have over starting your own business in the near future?' (1) No control to (7) Full control. The subjective norms variable was measured in two steps. First, subjects were asked to identify the significant others. Second, subjects reported the perception their significant others had about them starting a business, from (1) extremely unfavorable to (7) extremely favorable. Lastly, desire was measured using four items or statements on a seven-point interval scale between (1) very strongly disagree and (7) very strongly agree. One of these statements is for example: 'Starting up my own business is my strong desire.'

\section{Reliability and discriminant validity}

Tables 1 (a) and (b) provide statistics relating to reliability and discriminant validity for each construct in our model for each group of individuals namely, with growth-oriented or independence-oriented intentions.

Discriminant validity, or the degree to which items differentiate between constructs, can be assessed by comparing the Average variance Extracted (AVE) with the corresponding correlation. 
Table 1 (a). Correlations, AVE, and Composite Reliabilities for the growth oriented subsample.

\begin{tabular}{llllllll}
\hline & Attitude & $\begin{array}{l}\text { Beh__ } \\
\text { control }\end{array}$ & Desire & $\begin{array}{l}\text { I_trowth } \\
\text { Emo }\end{array}$ & $\begin{array}{l}\text { Neg_A } \\
\text { Emos_A_ } \\
\text { Emo }\end{array}$ & $\begin{array}{l}\text { Sub_ } \\
\text { Norms }\end{array}$ \\
\hline Attitude & $\mathbf{0 . 6 0}$ & & & & & & \\
Beh_control & 0.227 & $\mathbf{0 . 6 2}$ & & & & & \\
Desire & 0.478 & 0.271 & $\mathbf{0 . 6 4}$ & & & & \\
I_Growth & 0.236 & 0.323 & 0.453 & $\mathbf{0 . 5 8}$ & & & \\
Neg_A Emo & 0.032 & 0.271 & 0.254 & 0.309 & $\mathbf{0 . 6 9}$ & & \\
Pos_A_Emo & 0.435 & 0.081 & 0.416 & 0.115 & 0.244 & $\mathbf{0 . 6 5}$ & \\
Sub_Norms & 0.200 & 0.200 & 0.381 & 0.347 & 0.277 & -0.031 & $\mathbf{0 5 2}$ \\
Composite & 0.81 & 0.83 & 0.90 & 0.73 & 0.91 & 0.89 & 0.80 \\
Reliability & 0.79 & 0.73 & 0.87 & 0.70 & 0.90 & 0.84 & 0.70 \\
Cronbach Alpha & 0.79 &
\end{tabular}

Diagonal bold $=$ AVE; correlations $>0.20$ Sign. $=0.00$; correlations $>0.25$ Sig. 0.000 ; correlations $0.15<$ NS.

For every construct, AVE should exceed the construct's correlation (Fornell \& Larcker, 1981). Also note from the correlations, attitude is not highly correlated with anticipated emotions despite the fact the attitude measures included items related to affect.

The results from this comparison support the discriminant validity for all ten constructs. AVE measures are above the recommended threshold of 0.50 .

Note that PLS-SEM emphasizes the use of Composite Reliability (CR) rather than Cronbach alpha since it is generally regarded as a more appropriate criterion of internal consistency reliability (Hair, Ringle \& Sarstedt, 2012).

Table 1 (b). Correlations, AVE, and Composite Reliabilities for the independence oriented subsample.

\begin{tabular}{llllllll}
\hline & Attitude & $\begin{array}{l}\text { Beh_} \\
\text { control }\end{array}$ & Desire & $\begin{array}{l}\text { I_- } \\
\text { Indepen }\end{array}$ & $\begin{array}{l}\text { Neg_A } \\
\text { Emo }\end{array}$ & $\begin{array}{l}\text { Pos_A_ } \\
\text { Emo }\end{array}$ & $\begin{array}{l}\text { Sub_ } \\
\text { Norms }\end{array}$ \\
\hline Attitude & $\mathbf{0 . 7 5}$ & & & & & & \\
Beh_control & 0.223 & $\mathbf{0 . 8 0}$ & & & & & \\
Desire & 0.481 & 0.261 & $\mathbf{0 . 8 0}$ & & & & \\
I_Indepen & 0.119 & -0.190 & 0.29 & $\mathbf{0 . 7 5}$ & & & \\
Neg_A Emo & 0.021 & 0.214 & 0.193 & 0.103 & $\mathbf{0 . 8 3}$ & & \\
Pos_A_Emo & 0.451 & 0.097 & 0.412 & 0.140 & 0.230 & $\mathbf{0 . 8 1}$ & \\
Sub_Norms & 0.206 & 0.249 & 0.322 & 0.027 & 0.225 & -0.039 & $\mathbf{0 . 7 1}$ \\
Composite Reliability & 0.83 & 0.85 & 0.90 & 0.83 & 0.92 & 0.89 & 0.81 \\
Cronbach Alpha & 0.74 & 0.74 & 0.86 & 0.74 & 0.90 & 0.84 & 0.69 \\
\hline
\end{tabular}

diagonal bold $=$ AVE; Correlations $>0.20$ and $0.24<$ Sign. $=0.01$; correlations $>0.25$ Sig. 0.001; correlations $0.15<$ No Significant. 
All composite reliabilities are high except for intention with growth orientation, 0.73 , but this is still within the minimum acceptable cut off.

The correlations in Tables 1 (a) and (b) reveal that attitude and anticipated emotions have discriminant validity, given the reasonably low correlations. The association is also in the expected direction. There is a positive correlation, as expected, between negative anticipated emotions and desire. Note, statements measuring the former are rated with high values ( $7=$ very much so) but are written in the negative, e.g. "If you did not start your own business, you will feel frustrated".

\section{ANALYSIS AND STUDY}

Table 2 presents the findings for the path least squares model for our two subsamples. Since SmartPLS does not provide goodness of fit measures, we have generated statistical values by bootstrapping (2,000 samples; sign changes $=$ individual changes).

Column three reveals that desire to start a business with a growth orientation is significantly predicted by positive anticipated emotions, attitude, subjective norms, and perceived behavioral control/self-efficacy. Thus, hypotheses $\mathrm{H} 2(\mathrm{a}), \mathrm{H} 3, \mathrm{H} 4$, and $\mathrm{H} 6$, are supported by the data. The independent variables explain $40 \%\left(R^{2}\right)$ of the variance of desire. Intention to become an entrepreneur with an orientation for growth is significantly explained by desire and perceived behavioral control $\left(R^{2}=0.41\right)$. Hence, $\mathrm{H} 1(\mathrm{a})$ and $\mathrm{H} 5(\mathrm{a})$ are both supported by the data.

The second column in Table 2 presents the results for the independenceoriented subsample. Two hypothesized paths failed to reach statistical significance, namely, negative anticipated emotions, $\mathrm{H} 2(\mathrm{~b})$, and perceived behavioral control/self-efficacy, (H6). The latter does not have a statistically significant effect in predicting either desire or intention.

Attitude, positive anticipated emotions, and subjective norms explain $36 \%$ of the variance $\left(R^{2}\right)$ of the construct desire. Intention to start a business with an orientation for independence is explained marginally $\left(R^{2}=0.08\right)$ by desire only.

Tests of differences in slopes were conducted (Paternoster, Brame, Mazerolle \& Piquero, 1998) to determine if the models for the two groups differed in any paths. The fourth column in Table 2 presents our results. The hypothesized model appears to work well for both groups except for one path. Behavioral control is negatively associated with independence-oriented intentions (although not statistically significant), whereas it is positively, and statistically significant related to growth-oriented intentions. Desire had a stronger influence on intention to become an entrepreneur for growth 
$(B=0.40)$ than for independence $(B=0.28)$, albeit the differences are not statistically significant. Both values have also the correct sign.

Table 2. Path coefficients and test of differences

\begin{tabular}{|c|c|c|c|}
\hline & $\begin{array}{l}\text { (Gamma/ Beta) } \\
\text { Intention for } \\
\text { Independence }(n=108)\end{array}$ & $\begin{array}{l}\text { (Gamma/ Beta) } \\
\text { Intention for Growth } \\
(\mathrm{n}=90)\end{array}$ & $\begin{array}{l}\text { Z-value test; Statistical } \\
\text { Significance }\end{array}$ \\
\hline $\begin{array}{l}\text { Desire } \rightarrow \\
\text { Intention }\end{array}$ & $\begin{array}{l}B=0.28 \\
(t=4.64) * * \\
(S E=0.06)\end{array}$ & $\begin{array}{l}B=0.40(t=5.74)^{* *} \\
(S E=0.07)\end{array}$ & $\begin{array}{l}\mathrm{Z}=1.30 \\
\mathrm{n} / \mathrm{s}\end{array}$ \\
\hline $\begin{array}{l}\text { Beh. Control / } \\
\text { self-efficacy } \rightarrow \\
\text { Intention }\end{array}$ & $\begin{array}{l}B=-0.19 \\
(t=1.41) \\
(S E=0.15)\end{array}$ & $\begin{array}{l}\beta=0.23 \\
(t=3.30)^{* *} \\
(S E=0.07)\end{array}$ & $\begin{array}{l}Z=4.24 \\
p<0.001\end{array}$ \\
\hline (DV = Intention) & $R^{2}=0.08$ & $R^{2}=0.41$ & \\
\hline Attitude $\rightarrow$ Desire & $\begin{array}{l}\gamma=0.30 \\
(t=5.02) * * \\
(S E=0.06)\end{array}$ & $\begin{array}{l}y=0.27 \\
(t=4.12) * * \\
(S E=0.06)\end{array}$ & $\begin{array}{l}Z=0.35 \\
n / s\end{array}$ \\
\hline $\begin{array}{l}\text { Beh. Control/self- } \\
\text { efficacy } \rightarrow \text { Desire }\end{array}$ & $\begin{array}{l}\gamma=0.10 \\
(\mathrm{t}=1.26) \mathrm{n} / \mathrm{s} \\
(\mathrm{SE}=0.08)\end{array}$ & $\begin{array}{l}y=0.12 \\
(t=1.93)^{*} \\
(S E=0.06)\end{array}$ & $\begin{array}{l}Z=0.25 \\
n / s\end{array}$ \\
\hline $\begin{array}{l}\text { Pos_A_Emo } \rightarrow \\
\text { Desire }\end{array}$ & $\begin{array}{l}y=0.26 \\
(t=3.2)^{* *} \\
(\mathrm{SE}=0.08)\end{array}$ & $\begin{array}{l}\gamma=0.29 \\
(t=3.37) * * \\
(S E=0.08)\end{array}$ & $\begin{array}{l}Z=0.26 \\
n / s\end{array}$ \\
\hline $\begin{array}{l}\text { Neg_A_E } \rightarrow \\
\text { Desire }\end{array}$ & $\begin{array}{l}y=0.05 \\
(t=1.05) \mathrm{n} / \mathrm{s} \\
(\mathrm{SE}=0.04)\end{array}$ & $\begin{array}{l}\nu=0.04 \\
(t=0.88) \mathrm{n} / \mathrm{s} \\
(\mathrm{SE}=0.04)\end{array}$ & $\begin{array}{l}\mathrm{Z}=0.0 \\
\mathrm{n} / \mathrm{s}\end{array}$ \\
\hline Subj_N $\rightarrow$ Desire & $\begin{array}{l}y=0.21 \\
(t=3.70) * * \\
(S E=0.05)\end{array}$ & $\begin{array}{l}y=0.29 \\
(t=4.40) * * \\
(S E=0.06)\end{array}$ & $\begin{array}{l}Z=1.02 \\
n / s\end{array}$ \\
\hline (DV = Desire) & $R^{2}=0.36$ & $R^{2}=0.40$ & \\
\hline
\end{tabular}

Beh. Control. = Behavioural control; Pos_A_Emo = Positive Anticipated Emotions; Subj $\mathrm{N}=$ Subjective Norms, DV =Dependent Variable. $\mathrm{T}=\mathrm{T}$ value, $\mathrm{SE}=\mathrm{Standard}$ Error. $\mathrm{n} / \mathrm{s}=$ no significant at $0.05{ }^{*}$ two-tailed $\mathrm{p}$-value $=0.05{ }^{* *}$ two-tailed $\mathrm{p}$-value $<0.001$

\section{Test of mediation}

Test of mediation followed the procedure in Baron and Kenny (Kenny, 2013) and by applying the Sobel test (Soper, 2013; Warner, 2012). The direct effects (B) of attitude on intentions is 0.11 (2-tailed significance $=0.005$; Sobel test statistic $=2.77$ ) meaning that for a one-standard deviation increase in $z$ attitude, a .11 increase in $z$ intention is predicted through the mediating variable $z$ desire. Positive anticipated emotions $(B=0.11 ; 2$-tailed significance $=0.02$; Sobel test statistic $=2.28)$, subjective norms $(B=0.12 ; 2$-tailed significance $=$ 0.02 ; Sobel test statistic $=2.26)$, and perceived behavioral control $(B=-.19 ; t=$ 2.68) all have significant direct effects on intentions to start a business with a growth orientation. Desire appears to only partially mediate the effect of the aforementioned constructs, thus, $\mathrm{H7}$ is only partially supported by the data. 
The procedure carried out to determine the mediating effect of desire on the independence- oriented subsample is the same as above. Desire carries statistically significant mediating effects for attitude $(B=0.08$; $t$-value $=3.59$ ), and subjective norms ( $B=0.07$; $t$-value $=3.43$ ) only. Lastly, we omit the mediating variable altogether from our proposed model to determine whether or not desire adds any explanatory power. When desire is dropped from the model, the direct effects of beliefs, anticipated emotions, and attitudes explain $\left(R^{2}\right)$ only 24 percent of the variation in intentions for growth, and $\left(R^{2}\right)$ only 10 percent of the variation in intentions for independence versus $\mathrm{R}^{2}=0.41$ and 0.08 respectively, when desire is included. We thus conclude that desire explains more of the variation in intentions of individuals with well-defined intentions, such as entrepreneurs with an orientation for growth.

\section{DISCUSSION}

In this study, respondents were presented with affective attitude (e.g. starting a business is punishing/ rewarding) and instrumental attitude scales (e.g. starting a business is advantageous/ disadvantageous). Our results reveal that in both cases, attitude contributed directly and indirectly to predicting entrepreneurial intentions for independence and for growth. Affective attitude however was a stronger predictor than instrumental attitude, suggesting perhaps that the affective component of attitude is more salient in people's minds, a finding that is consistent with several studies that have distinguished between the two dimensions (Lowe et al., 2002; French et al., 2005). Interestingly, we find little evidence to suggest that desire completely mediates the impact of beliefs and attitude on intentions. One should consider however the size of the mediation effect and the statistical significance (Hair, Ringle, \& Sarstedt, 2013) when evaluating our results. It appears as though mediation through desire explains only a small part of the total effect of the independent variables on intentions. Unlike previous studies by Bagozzi and colleagues (Bagozzi \& Dholakia, 2006; Perugini \& Bagozzi, 2001), our research shows, attitude influences intention directly, even after controlling for the mediation of desire. One explanation for this may relate to the low reliability or convergent validity of the mediator. Measurement error may also explain our results, but this is not uncommon in the psychology literature (Rucker, Preacher, Tormala \& Petty, 2011). It may also be the case that desires are not well formed in our subsamples preventing us from capturing the full effect of our proposed predictors (Bagozzi \& Yi, 1989). Subjective norms refer to the social pressures entrepreneurs face when starting a new business. Comparing the two samples, the effect of subjective norms on intentions was not significantly different. In relative terms, subjective norms are just 
as important as attitude and positive -anticipated emotions in predicting intentions. In this study, social norms include the influence of colleagues or co-workers, friends and family. Both groups ascribed the highest weight to family member approval, followed by approval from friends. These findings reveal that potential entrepreneurs are influenced by the opinions of these two significant others, and play an important role in raising sentiments that infuse or diffuse desire. Importantly, these results are in support of hypothesis 4. Our proposed model includes the psychological concept of anticipated emotions, that is, the expected feelings or sentiments towards succeeding or failing in starting a business. Positive but not negative anticipated emotions had a direct and indirect effect on intentions for both groups. The fact that positive anticipated emotions have a direct influence on intentions implies that, in addition to inducing an intention to act through desire, it also has an automatic effect. It is surprising that negative anticipated emotions had no significant effect on either group. One explanation for this may be that negative anticipated emotions are not strong enough to impact desire. A second reason may relate to the concept of self-regulation. Regulatory focus is defined as a person's orientation towards future goals and consists of two types of orientations: promotion focus and prevention focus (Bryant, 2007). Because promotion focus is closely related to positive effects and highlights positive gains more than negative aspects, it is possible that positive anticipated emotions are driving eagerness (desire) which eventually translates into an intention to act. Negative anticipated emotions are presumably more related to a prevention focus - an orientation that seeks avoidance of potential losses - far removed in time since respondents do not see consequences of losing anything in the short term if they did not engage in the act of entrepreneurship. The effect of positive anticipated emotions is consistent with other studies that have included this variable as a predictor of intentions to improve the Theory of Planned Behaviour (French et al., 2005).

As posited in hypothesis 5 and 6 , perceived behavioral control (similar to perceived feasibility or self-efficacy in the SEE model) is an important antecedent of desire and intention only for the group with a growth orientation. That is, the more participants perceive the act of entrepreneurship is under their control, the greater is the intention to become an entrepreneur for growth. Note that perceived behavioral control had a negative sign for individuals wanting to start a business for independence. This suggests that these respondents perceived themselves as having less control over the act of starting a business. These findings are concordant with results from Douglas (2013) who finds Expected Self-Efficacy predicts growth but not independence-oriented intentions. The same negative association between independence oriented intentions and self-efficacy was also found. Perhaps 
these individuals do not need to have strong belief in their entrepreneurial capability, since starting a business with the intention to become independent may reflect a life-style decision. Further, these entrepreneurs do not seek profit maximization but work enjoyment (Douglas, 2013). In relation to perceived behavioral control and its influence on desire, the former influences the latter implying that when people judge themselves or appraise themselves as having the competency to perform entrepreneurial activities, the more they are infused with the desire to start a business. This result is understandable since a desire will lead to an intention to the extent that people perceive they can perform the entrepreneurial act. Fitzsimmons and Douglas (2011) call entrepreneurs who perceive themselves with high self-efficacy and high desirability 'natural entrepreneurs'.

Following the advice of previous studies to improve the theory of planned behavior (Perugini and Bagozzi, 2001; Slovic et al., 2002; Bagozzi and Dholakia, 2006), and considering the importance of the 'desire intention for profit', this research integrates the desire construct, which activates the intention to act, in our proposed model. Why do attitude, subjective norms, positive anticipated emotions and behavioral control have direct effects? One explanation suggests that respondents' desires are not self-motivating on their own, hence the need for antecedents such as behavioral control, attitude, and subjective norms. A second explanation relates to volitive desires as a manifestation of the will of people. Perhaps respondents do not have the will or a well formed desire to start a business, even though they have indicated an intention to do so. The goal to start a business may be perceived in a too distant future, which may have repercussions for desire. It is also possible that intentions, unlike desires, entail beliefs, thus, variables proposed in our model that reflect beliefs (e.g. subjective norms, behavioral control) are likely to have a direct effect on intentions. Lastly, the results of this study suggest that attitude may not be a suitable proxy for 'perceived desirability' as suggested elsewhere (Slovic et al., 2002), since it has a greater far reaching effect than desire on the prediction of intentions.

We expected potential entrepreneurs with an orientation for growth to be more influenced by desire, since growing a business requires much greater dedication and little time for work enjoyment (Douglas, 2013). Our results do appear to suggest this, as desire has greater explanatory power for the growth oriented group $\left(R^{2}=0.41\right)$ compared to the independence oriented group $\left(R^{2}=0.08\right)$. The explained variation for the latter group is quite low however, which may indicate that the intentions of these individuals in particular are not well formed. 


\section{CONCLUSIONS}

The formation of entrepreneurial intentions has followed two theoretical models, namely, the Theory of Planned Behavior (TPB) and the Shapero Entrepreneurial Event (SEE). Both models assume attitude provides a reason for forming an intention, but note that the SEE model substitutes attitude, as found in the TPB, for perceived desirability. More recently, the entrepreneurship literature has highlighted the fact that the TPB and the SEE are not motivational models (Bird, 2015; Schlaegel \& Koenig, 2014). Thus, our contribution to the extant literature in this regard is to demonstrate and test how 'desire' (a construct different from 'perceived desirability') activates or propels intentions in the context of new business formation. Bird (2015, p.158) has called for studies to move beyond basic or non-specific predictions of entrepreneurial intentions by applying existing models to "other entrepreneurial actions, including growth intentions". In that spirit, our study uses a sample of non-students to predict intentions to start a business with an orientation for growth and an orientation for independence. Our final contribution to the entrepreneurship literature is the inclusion of anticipated emotions in our proposed cognitive model. The data appear to be in support of our proposed modification. In particular, positive anticipated emotions were found to contribute significantly to predictions of desire, attitude, and subjective norms. We find partial support for our contention that desire fully mediates the effect of attitudes, anticipated emotions, subjective norms and behavioral control on intentions to start a business. Desire accounts for only eight percent of the variance in independence-oriented intentions, whereas it accounts for $41 \%$ of the variation in growth-oriented intentions. It may well be the case that desire is more associated with intentions when they are well formed and challenging.

One key point of difference between the two groups studied relates to the weak statistical significance of perceived behavioral control (self-efficacy) in predicting desire or intentions to start a business with an orientation for independence. This is probably the result of the lack of stability or an illformed independence-oriented intention.

\section{Implications}

The findings from this study may benefit entrepreneurs, investors and educators of entrepreneurship by providing a clearer understanding of how entrepreneurial intentions become energized. The concept of entrepreneurial desire provides this rationale. Practitioners may also be interested in understanding how entrepreneurial desire is formed. This study shows that attitudes (both instrumental and affective), positive anticipated 
emotions, subjective norms and perceived behavioral control coalesce into the entrepreneurial desire to start a business.

The desire for entrepreneurship can be ignited by making individuals think (or visualize) about the positive aspects of starting a business (of having achieved the goal of starting a business). This will elicit positive anticipated emotions or feelings that will serve as catalyst of desires.

Individuals must also be taught the skills required to be an entrepreneur. Desires may be unjustifiable if they are not accompanied by the perception of behavioral control.

The sample of entrepreneurs in this study acknowledges the influence of significant others, namely, friends and family in their decision to start a business. In many cases these individuals are likely to be the least critical of potential entrepreneurs. Aspiring entrepreneurs must be cautious of the opinions of relevant others. Although their comments and opinions may be encouraging, they are unlikely to constitute sound objective advice.

\section{Limitations}

This research study is not without its limitations. First, the sample studied is small and respondents were grouped on the basis of averages (a score of 4.5 or above) to answers to various statement items designed to measure intentions to start a business for growth or for independence. An individual may have agreed with one or more items for both growth-oriented and independence-oriented intention measures. To mitigate this issue, respondents were classified in one group over the other if their ratings were higher on one scale over the other. Future studies may strive to distinguish the two categories of intentions in a different manner to improve the robustness of our results in this study. Note however that the methodology employed in this study still reveals significant differences between the groups. Further, the variables used to measure intention, as adapted from Douglas (2013), may reflect behavioral expectations more so than behavioral intentions. Perhaps our results may change markedly if behavioral intention measures were used. Lastly, this study utilizes cross-sectional data, yet the constructs in our proposed model are likely to be time dependent. For instance, desires and intentions may vary over time. This study does not capture these dynamics in the data.

\section{References}

Ajzen, I. (1991). The theory of planned behavior. Organizational Behavior and Human Decision Processes, 50(2), 179-211. 
Ajzen, I. (Ed.). (1985). From Intentions to Actions: A Theory of Planned Behavior. New York: Springer-Verlag.

Ajzen, I., \& Madden, T. (1986). Prediction of goal directed behavior: attitudes, intentions, and perceived control. Journal of Experimental Social Psychology, 22(5), 453-474.

Amin, M. (2009). Necessity vs Opportunity Entrepreneurs th the Informal Sector (short note). Enterprise surveys note series; no. 17. Informality. Washington, DC: World Bank. Retrieved from http://documents. worldbank.org/curated/en/481511468006610563

Andrews, K., \& Kandel, D. (1979). Attitude and behavior: A specification of the contingent-consistency hypothesis. American Sociological Review, 44(2), 298-310.

Armitage, C., \& Conner, M. (1999). Dinstinguishing perceptions of control from self-efficacy: Predicting consumption of a low fat diet using the theory of planned behavior. Journal of Applied Social Psychology, 29(1), 72-90.

Bae, T. J., Qian, S., Miao, C., \& Fiet, J. O. (2014). The relationship between entrepreneurship education and entrepreneurial intentions: A metaanalytic review. Entrepreneurship Theory and Practice, 38(2), 217-254.

Bagozzi, R. (1992). The self-regulation of attitudes, intentions and behavior. Social Psychology Quarterly, 55(2), 178-204.

Bagozzi, R., Baumgartner, H., \& Pieters, R. (1998). Goal directed emotions. Cognition and Emotion, 12(1), 1-26.

Bagozzi, R., \& Dholakia, U. (2006). Antecedents and purchase consequences of customer participation in small group brand communities. International Journal of Research in Marketing, 23(1), 45-61.

Bagozzi, R., Dholakia, U. M., \& Basuroy, S. (2003). How effortful decisions get enacted: the motivating role of decision processes, desires, and anticipated emotions. Journal of Behavioral Decision Making, 16(4), 273295.

Bagozzi, R. P., \& Yi, Y. (1989). The degree of intention formation as a moderator of the attitude-behavior relationship. Social Psychology Quarterly, 52(4), 266-279.

Bandura, A. (1997). Self-efficacy: The Exercise of Control. NY: Worth Publishers. Bandura, A., \& Locke, E. (2003). Negative self-efficay and goal effects revisited. Journal of Applied Psychology, 88(1), 87-99.

Baum, R., \& Bird, B. (2010). The successful intelligence of high-growth entrepreneurs: Links to new venture growth. Organization Science, 21(2), 397-412.

Baum, R., \& Locke, E. (2004). The relationship of entrepreneurial traits, skill, and motivation to subsequent venture growth. Journal of Applied Psychology,, 89(4), 587-598.

Bird, B. (2015). Entrepreneurial intentions research: A review and outlook. International Review of Entrepreneurship, 13(3), 143-168. 
Bryant, P. (2007). Self-regulation and decision heuristics in entrepreneurial opportunity evaluation and exploitation. Management Decision, 45(4), 732-748.

Cardon, M. S., Foo, M.-D., Shepherd, D., \& Wiklund, J. (2012). Exploring the heart: Entrepreneurial emotion is a hot topic. Entrepreneurship Theory \& Practice, 36(1), 1-10.

Cheung, O. (2014). Are we seeing 'necessity' or 'opportunity entrepreneurs at large? Research in Business and Economics Journal, 9(August), 1-26.

Clore, L., Wyer, S., Dienes, B., Gasper, K., Gohm, C., \& Isbell, L. (2001). Affective feelings as feedback: Some cognitive consequences. In L. Martin \& L. Clore (Eds.), Theories of Mood and congnition: A user's handbook (pp. 27-62). NJ: Erlbaum.

Davis, W. (1984). Two senses of desire. Philosophical Studies: An International Journal for Philosophy in the Analytic Tradition, 45(2), 181-195.

Desai, S. (2011). Measuring entrepreneurship in developing countries. In W. Naude (Ed.), Entrepreneurship and Economic Development (pp. 94-75). Basingstoke: Palgrave-Macmillan.

Douglas, E. (2013). Reconstructing entrepreneurial intentions to identify predispositions for growth. Journal of Business Venturing, 28(5), 633651.

Drnovsek, M., \& Erikson, T. (2005). Competing models of entrepreneurial intentions. Economic and Business Review for Central and South-Eastern Europe, 7(1), 55-71.

Fazio, R. (Ed.). (1995). Attitudes as Object-Evaluation Associations: Determinants, Consequences, and Correlates of Attitude Accessibility. Mahwah, NJ: Earlbaum.

Fitzimmons, J., \& Douglas, E. (2011). Interaction between feasibility and desirability in the formation of entrepreneurial intentions. Journal of Business Venturing, 26(4), 431-440.

Fornell, C., \& Larcker, D. (1981). Evaluating structural equation models with unobservable variables and measurement errors. Journal of Marketing Research, 18(1), 39-50.

Franken, R. (1997). Human Motivation (4th ed.). Pacific Grove, CA: Brooks/ Cole.

French, D., Sutton, S., Hennings, S., Mitchell, J., Wareham, N., Griffin, S., . . . Kinmonth, A. (2005). The importance of affective beliefs and attitudes in the theory of planned behavior: Predicting intention to increase physical activity. Journal of Applied Psychology, 35(9), 1824-1848.

Gleicher, F., Boninger, D., Strathman, A., Armor, D., Hetts, J., \& Ahn, M. (1995). With an eye toward the future: The impact of counterfactual thinking on affect, attitudes, and behaviour. In J. Roese \& M. Olson (Eds.), What Might Have Been: The Social Psychology of Counterfactual Thinking. Mahwah, NJ: Erlbaum. 
Gollwitzer, P. (1996). The volitional benefits of planning. In P. Gollwitzer \& J. Bargh (Eds.), The Psychology of Action: Linking Cognition and Motivation to Behavior (pp. 287-312). New York: Guilford.

Gollwitzer, P., Heckhausen, H., \& Steller, B. (1990). Deliberative and implemental mind-sets: Cognitive tuning toward congruous thoughts and information. Journal of Personality and Social Psychology, 59(6), 1119-1127.

Grube, J., \& Morgan, M. (1990). Attitude-social support interactions: Contingent consistency effects in the prediction of adolescent smoking, drinking and drug use. Social Psychology Quarterly, 53(4), 329-339.

Hair, J. F., Ringle, C. M., \& Sarstedt, M. (2013). Editorial Partial Least Squares structural equation modeling: Rigorous applications, better results and higher acceptance. Long Range Planning, 46(3), 1-12.

Hair, J. F., Sarstedt, M., Pieper, T. M., \& Ringle, C. M. (2012). The use of partial least squares structural equation modeling in strategic management research: A review of past practices and recommendations for future applications. Long Range Planning, 45(5-6), 320-240.

Kautonen, T., van Gelderen, M., \& Fink, M. (2015). Robustness of the theory of planned behavior in predicting entrepreneurial intentions and actions. Entrepreneurship Theory and Practice, 39(3), 655-674.

Kenny, D. A. (2013). Mediation. Retrieved from http://davidakenny.net/cm/ mediate.htm

Krueger, Jr. N. (1993). The impact of prior entrepreneurial exposure on perceptions of new venture feasibility. Entrepreneurship Theory \& Practice, 18(1), 5-21.

Krueger Jr. N., \& Carsrud, A. (1993). Entrepreneurial intentions: Applying the theory of planned behavior. Entrepreneurial \& Regional Development, 5(4), 315-330.

Krueger Jr. N., Reilly, M., \& Carsrud, A. (2000). Competing models of entrepreneurial intentions. Journal of Business Venturing, 15(6), 422432.

Li, Y. (2011). Emotions and new venture judgement in China. Asia Pacific Journal of Management, 28, 277-298.

Lowe, R., Eves, F., \& Carroll, D. (2002). The influence of affective and instrumental beliefs on exercise intentions and behavior: A longitudinal analysis. Journal of Applied Social Psychology, 32(6), 1241-1252.

Malle, B., \& Knobe, J. (1997). The folk concept of intentionality. Journal of Experimental Social Psychology 33(2), 101-121.

McMullen, J. S., \& Dimov, D. (2013). Time and the entrepreneurial journey: the problems and promise of studying entrepreneurship as a process. Journal of Management Studies, 50(8), 1481-1512.

Mellers, B., \& Chang, S.-J. (1994). Representations of risk judgments. Organizational Behavior and Human Decision Processes, 57(2), 167-184. 
Miller, W. (1994). Childbearing motivations, desires, and intentions: a theoretical framework. Genetic, Social, and General Psychology Monographs, 120(2), 223-258.

Miller, W., \& Pasta, D. (1995). Behavioral intentions: Which one predict fertility behavior in married couples? Journal of Applied Psychology, 25(6), 530-555.

Nelissen, R., de Vet, E., \& Zeelenberg, M. (2011). Anticipated emotions and effort allocation in weight goal striving. British Journal of Health Psychology, 16(1), 201-212.

Okasaki, S. (2009). Social influence model and electronic word of mouth. International Journal of Advertising, 28(3), 439-472.

Paternoster, R., Brame, R., Mazerolle, P., \& Piquero, A. (1998). Using the Correct Statistical Test for the Equality of Regression Coefficients. Criminology, 36(4), 859-866.

Perugini, M., \& Bagozzi, R. (2001). The role of desires and anticipated emotions in goal-directed behaviours: Broadening and deepening the theory of planned behaviour. British Journal of Social psychology, 40(1), 79-98.

Perugini, M., \& Bagozzi, R. (2004). The distinction between desires and intentions. European Journal of Social Psychology, 34(1), 69-84.

Perugini, M., \& Conner, M. (2000). Predicting and understanding behavioral volitions: the interplay between goals and behaviors. European Journal of Social Psychology, 30(5), 705-731.

Pfister, H.-R., \& Bohm, G. (2008). The multiplicity of emotions: A framework of emotional functions in decision making. Judgment and Decision Making, 3(1), 5-17.

Reynolds, P., Camp, S., Bygrave, W., Autio, E., \& Hay, M. (2002). The Global Entrepreneurship Monitor (2001 Executive Report). London: London Business School and Babson College.

Rodgers, W., Conner, M., \& Murray, T. (2008). Disntinguishing among perceived control, perceived difficulty, and self-efficacy as determinants of intentions and behaviours. British Journal of Social Psychology, 47(Pt4), 607-630.

Rucker, D., Preacher, K., Tormala, Z., \& Petty, R. (2011). Mediation analysis in social psychology: Current practices and new recommendations. Social and Personality Psychology Compass, 5/6, 359-371.

Sandberg, T., \& Conner, M. (2008). Anticipated regret as an additional predictor in the theory of planned behaviour: A meta-analysis. British Journal of Social Psychology, 47, 589-606.

Schlaegel, C., \& Koenig, M. (2014). Determinants of Entrepreneurial Intent: A Meta-Analytic Test and Integration of Competing Models. Entrepreneurship Theory and Practice, 38(2), 291-332.

Schlosser, T., Dunning, D., \& Fetchenhauer, D. (2013). What a feeling: The role of immediate and anticipated emotions in risky decisions. Journal of Behavioral Decision Making, 26(1), 13-30. 
Sitkin, B., \& Weingart, L. (1995). Determinants of risky-decision making behavior: A test of the mediating role of risk perceptions and propensity. Academy of Management Journal, 38(6), 1573-1592.

Slovic, P., Finucane, M., Peters, E., \& MacGregor, D. (2002). The affect huristic. In T. Gilovich \& D. Griffin (Eds.), Heuristics and Biases: The Psychology of Intuitive Judgment (pp. 397-420). New York: Cambridge University Press.

Soper, D. (2013). Statistics Calculators Retrieved from http://www.danielsoper. com/statcalc3/calc.aspx?id=31

Teasdale, D., \& Barnard, J. (1993). Affect, Cognition and Change: Re-Modelling Depressive Thought. Hove, U.K.: Lawrence Erlbaum Associates Ltd.

Van Gelderen, M., Kautonen, T., \& Fink, M. (2015). From entrepreneurial intentions to actions: Self-control and action-related doubt, fear, and aversion. Journal of Business Venturing, 30(5), 655-673.

Warner, R. (2012). Applied Statistics: From Bivariate through Multivariate Techniques (2nd ed.). Thousand Oaks:Ca.: Sage.

Wood, M., \& Williams, D. (2014). Opportunity evaluation as a rule-based decision making. Journal of Management Studies, 51(4), 573-602.

Zampetakis, L., Lerakis, M., Kafetsios, K., \& Moustakis, V. (2016). Anticipated emotions towards new venture creation: A latent profile analysis of early stage career starters. The International Journal of Management Education, 14(1), 28-38.

\section{Appendix}

Sample demographic characteristics

\begin{tabular}{llll}
\hline Demographic & Categories & Frequency & Percent \\
\hline \multirow{4}{*}{ Gender } & Male & 140 & $66.4 \%$ \\
& Female & 71 & $33.6 \%$ \\
& Total & 211 & 100 \\
\hline \multirow{4}{*}{ Age } & less than 20 & 6 & $2.8 \%$ \\
& $21-29$ & 82 & $38.9 \%$ \\
& $30-39$ & 76 & $36.0 \%$ \\
& $40-49$ & 29 & $13.7 \%$ \\
& $50+$ & 18 & $8.5 \%$ \\
& Total & 211 & 100 \\
\hline \multirow{4}{*}{ Marital status } & 77 & $36.5 \%$ \\
& Single & 121 & $57.3 \%$ \\
& Married & 13 & $6.2 \%$ \\
& Others & 211 & 100 \\
\hline
\end{tabular}




\begin{tabular}{llll}
\hline & & & \\
\hline Demographic & Categories & Frequency & Percent \\
\hline In which & Private Sector & 148 & $70.1 \%$ \\
business & Public Sector & 47 & $22.3 \%$ \\
sector are you & Not Working / Retired & 16 & $7.6 \%$ \\
working? & Total & 211 & 100 \\
\hline \multirow{3}{*}{ How many } & Less than 3 years & 43 & $20.4 \%$ \\
years of work & 3-6 years & 50 & $23.7 \%$ \\
experience do & 7-10 years & 51 & $24.2 \%$ \\
you have? & More than 10 years & 67 & $31.8 \%$ \\
& Total & 211 & 100 \\
\hline \multirow{5}{*}{ Education } & High school & 15 & $7.1 \%$ \\
& Two years college & 31 & $14.7 \%$ \\
& (Diploma) & & $62.1 \%$ \\
& Undergraduate Degree & 131 & $16.1 \%$ \\
& (Bachelors) & & 100 \\
\hline & Postgraduate (Master & 34 & \\
& \& PhD) & 211 & \\
& Total & & \\
\hline
\end{tabular}

\section{Abstrakt (in Polish)}

Celem niniejszej pracy jest integracja koncepcyjnego i empirycznego podejścia do przewidywania i wyjaśnienia intencji przedsiębiorczych. Szczególnie, testowanie modelu, który odpowiada za motywację przedsiębiorcy, jako istotnego czynnika powszechnie pominiętego $w$ aktualnych teoriach z zakresu intencji przedsiębiorczych. Badamy rolę chęci przedsiębiorców (odrębnq od koncepcji zamiaru) jako wyznacznika dwóch wyróżniajq̨cych intencji przedsiębiorczych. Badania te potwierdzajq najnowsze wyniki badań, które podkreślajq znaczenie identyfikacji intencji w rozpoczęciu działalności gospodarczej o orientacji na rzecz wzrostu w przeciwieństwie do substytucji dochodów. Ponadto, podczas gdy rola emocji stała się ważnym czynnikiem w przedsiębiorczości, przewidywane emocje zyskały bardzo niewiele uwagi w bieżqcej literaturze. Wykorzystujq̨c próbę badawczq z Kuwejtu, artykuł ten stwierdza, że pragnienie jest silniejszym predyktorem intencji zorientowanych na wzrost dochodów niż intencje zorientowane na substytucję dochodów. Również chęci przedsiębiorcze częściowo i pośrednio wpływajq na postawę, spodziewane emocje i intencje przedsiębiorcze.

Słowa kluczowe: przedsiębiorczość, intencje, pragnienia, postawy, oczekiwane emocje. 


\section{Biographical notes}

Hernan E. Riquelme (Ph.D.) is professor of Entrepreneurship and Marketing at Gulf University for Science and Technology. He has been in academia for more than twenty years. He has also worked for a development bank with headquarters in the Netherlands, and as a fund manager in the United Kingdom.

Abdullah M. Al-Lanqawi is a graduate from Maastricht School of Management, currently a board member at MEFIC Capital and fund manager at Al-Amin Money Market Fund, Ahli United Bank Kuwait. 